\title{
REFINEMENTS OF THE MAJORIZATION THEOREMS VIA FINK IDENTITY AND RELATED RESULTS
}

\author{
SAdiA KHALID, Josip PEČARIĆ AND ANA VuKelić
}

\begin{abstract}
The well known majorization theorem ( see [5, p. 11] and [7, p. 320] ) plays an important role in our paper. By using A. M. Fink's identity in the majorization difference, we obtain an interesting identity and with the help of this useful identity, we obtain many significant results. We investigate the bounds for this identity, by using Grüss-type inequalities and we also present some results relating to the Ostrowski-type inequality.
\end{abstract}

Mathematics subject classification (2010): 26A51, 26D15.

Keywords and phrases: Logarithmic convexity, divided difference, $n$-convex function, majorization, Fink's identity, Čebyšev functional, Grüss-type inequality, Ostrowski-type inequality, exponential convexity.

\section{REFERENCES}

[1] P. Cerone, S. S. Dragomir, Some new Ostrowski-type bounds for the Čebyšev functional and applications, J. Math. Inequal. 8 (1) (2014), 159-170.

[2] A. M. FInK, Bounds of the deviation of a function from its avereges, Czechoslovak Math. J. 42 (117) (1992), 289-310.

[3] L. FUCHS, A new proof of an inequality of Hardy-Littlewood-Pólya, Mat. Tidsskr, B (1947), 53-54.

[4] J. L. W. V. JENSEN, Sur les fonctions convexes et les inégalités entre les valeurs moyennes, Acta Math. 30 (1) (1906), 175-193.

[5] A. W. MARShall, I. OlKin AND B. C. ARNOLD, Inequalities; Theory of majorization and its Applications (Second Edition), Springer Series in Statistics, New York 2011.

[6] J. PEČARIĆ, On some inequalities for functions with nondecreasing increments, J. Math. Anal. Appl., 98 (1) (1984), 188-197.

[7] J. Pečarić, F. Proschan, Y. L. Tong, Convex Functions, Partial Orderings, and Statistical Applications, Academic Press, New York, 1992.

[8] J. PeČARIĆ, J. PERIĆ, Improvements of the Giaccardi and the Petrović inequality and related Stolarsky type means, An. Univ. Craiova Ser. Mat. Inform. 39 (2012), 65-75.

[9] D. V. WidDER, The Laplace transform, Princeton Univ. Press, New Jersey, 1941, 1946. 